\title{
СВЯЗЬ СОЦИАЛЬНО-ПСИХОЛОГИЧЕСКИХ ХАРАКТЕРИСТИК И ПОКАЗАТЕЛЕЙ ЭТНИЧЕСКОЙ ИДЕНТИЧНОСТИ У МОЛОДЕЖИ С РАЗНЫМИ РЕЛИГИОЗНЫМИ ВЗГЛЯДАМИ
}

\section{RELATIONSHIP OF SOCIO- PSYCHOLOGICAL CHARACTERISTICS AND INDICATORS OF ETHNIC IDENTITY AMONG YOUNG PEOPLE WITH DIFFERENT RELIGIOUS VIEWS}

Yu. Buzykina

Summary: The article presents the results of a study of the relationship of socio-psychological characteristics with indicators of ethnic identity among young people with different religious views. Different degrees of expression of indicators of ethnic and religious identity were found depending on the religion. Connections of interpersonal relations with indicators of ethnic identity are established. The correlation of components of religious identity with types of ethnic identity was revealed, both among Orthodox students and young people who profess Islam.

Keywords: ethnic identity, religious identity, ethnic affiliation, interpersonal relations, youth, religious views.

\author{
Бузыкина Юлия Сергеевна \\ к.nсх.н., доцент, ФГБОУ ВО «Пензенский государственный \\ университет» \\ ylamart@yandex.ru
}

Аннотация: В статье представлены результаты исследования связи социально-психологических характеристик с показателями этнической идентичности у молодежи с разными религиозными взглядами. Обнаружена различная степень выраженности показателей этнической и религиозной идентичности в зависимости от вероисповедания. Установлены связи межличностных отношений с показателями этнической идентичности. Выявлена корреляция компонентов религиозной идентичности с типами этнической идентичности, как у православных студентов, так и у молодежи, исповедующей ислам.

Ключевые слова: этническая идентичность, религиозная идентичность, этническая аффилиация, межличностные отношения, молодежь, религиозные взгляды.

ности молодых людей связана с недостаточной изученностью данного компонента, а знание о закономерностях формирования религиозной идентичности может способствовать решению межэтнических проблем, на основе которых возникают проблемы интолерантности и экстремизма на религиозной основе, а также способствовать оптимизации межличностных отношений молодежи разных этнических групп [7].

Анализ трудов зарубежных и отечественных исследователей, занимающихся изучением показателей этнического самосознания - этнической толерантности (Г.Г. Абдулкаримов, В.Г. Крысько, Н.М. Лебедева [4], В.С. Собкин, Г.У. Солдатова и др.), этнической идентичности (Т.Г. Стефаненко [8], В.Ю. Хотинец, О.Е. Хухлаев [11], Э. Эриксон и др.), социально-психологических характеристик (Г.М. Андреева [1], А.Г. Асмолов, Т. Лири, А.В. Мудрик, Ж. Пиаже и др.), религиозности молодежи (В.А. Ильин, Г. Олпорт, О.Е. Хухлаев, Van Camp D. и др.), а также знание специфики формирования религиозной идентичности, учет особенностей этнической идентичности участников межэтнического взаимодействия, может способствовать решению межэтнических проблем, связанных с ростом интолерантности и проявлений экстремизма на религиозной основе в молодежной среде. 
Таким образом, социально-психологические характеристики и показатели этнической идентичности молодежи с разными религиозными взглядами остаются изученными не в полной мере.

Эмпирическое исследование было проведено на базе ФГБОУ ВО «Пензенский государственный университет». Выборку составили испытуемые в возрасте 18-25 лет (студенты с православными взглядами и студенты, исповедующие ислам). Использованы диагностические методики для выявления типов этнической идентичности (Г.У. Солдатова, С.В. Рыжова) [5], этнической аффилиации (Г.У. Солдатова, С.В. Рыжова), межличностных отношений Т. Лири [3], адаптированная версия опросника Д. Ван Камп для измерения индивидуальных/социальных компонентов религиозной идентичности (В.А. Шорохова, О.Е. Хухлаев) [11].

Полученные результаты были подвергнуты математико-статистической обработке данных с помощью t-критерия Стьюдента, критерия U-Манна-Уитни, ранговой корреляции $\mathrm{r}_{\mathrm{s}}$ Спирмена.

Установлено, что существует различная степень выраженности показателей этнической и религиозной идентичности в зависимости от вероисповедания.

Так, в группе молодых людей с православными взглядами по сравнению с молодежью, исповедующей ислам, выше показатели компонента религиозной идентичности «Духовная идентичность» $\left(\mathrm{t}_{\text {эмп }}=3,2, \mathrm{p} \leq 0,01\right)$, более выражена «Позитивная этническая идентичность» $\left(U_{\text {эмп }}=104, p \leq 0,01\right)$.

Степень выраженности «Этноизоляционизма» выше в группе испытуемых, исповедующих ислам, чем у православной молодежи $\left(U_{\text {эмп }}=132, \mathrm{p} \leq 0,05\right)$.

На основе полученных результатов можно сделать вывод о том, что для молодых людей с православными взглядами важнее личное общение с Богом, чем участие в религиозных мероприятиях, включающих соблюдение формальных ритуалов и правил, чем для молодых людей, исповедующих ислам.

Также молодые люди с православными взглядами имеют более высокую толерантность и готовы к уважительному отношению и контактам с другими этническими группами. У них доминируют позитивные установки и чувства, как к своей группе, так и к представителям других этносов.

Для молодых людей, исповедующих ислам, более характерно признание потребности в «очищении» своей культуры, что может находить выражение в запрете на межнациональные браки. При этом доминирует мысль об обособлении своей этнической группы от других народов, что достижимо путем минимизирования контактов с ними.

С помощью критерия $\mathrm{r}_{\mathrm{s}}$ Спирмена у молодых людей с православными взглядами выявлены следующие статистически значимые связи межличностных отношений и показателей этнической идентичности:

1. дружелюбного типа межличностных отношений и этнической индифферентности $\left(r_{s}=0,49, p \leq 0,01\right)$. Это говорит о том, что при неопределенности этнической идентичности для молодых людей с православными взглядами в большей мере характерно доминирование дружелюбного типа межличностных отношений, который выражается в принятии, социальном одобрении, стремлении к общительности в отношениях;

2. подчиняемого типа и позитивной этнической идентичности $\left(r_{s}=-0,522, p \leq 0,01\right)$. Так, чем выше показатели позитивной этнической идентичности, выражающейся в уважительном отношении как к представителям своего этноса, так и к другим народам, тем менее выражен подчиняемый тип межличностных отношений православной молодежи, которой в меньшей степени характерны застенчивость, смущенность, кротость, стремление подчиняться более авторитетным личностям;

3. зависимого типа и этноэгоизма $\left(r_{s}=-0,451, p \leq 0,01\right)$. Чем больше выражено у испытуемых напряженное общение с представителями других этнических общностей, тем в меньшей степени в межличностных отношениях проявляются страхи и опасения, неуверенность, зависимость от их мнения;

4. агрессивного типа межличностных отношений и этноизоляционизма $\left(r_{s}=0,58, p \leq 0,01\right)$. Так, чем выше степень убежденности в превосходстве своего народа, ярче негативное отношение к другим этническим группам, тем больше возрастает доминирование агрессивного типа межличностных отношений, проявляющегося в жестокости, резкости, откровенном враждебном отношении по отношению к другим.

В группе студентов, исповедующих ислам, статистически значимых связей межличностных отношений с показателями этнической идентичности выявлено не было.

При этом, как в группе православных студентов, так и у представителей ислама выявлена корреляция компонентов религиозной идентичности с типами этнической идентичности.

Установлено, что у студентов-мусульман при высоком уровне этноизоляционизма (убежденности в превосходстве своего народа, ксенофобии и т.п.) значимую 
роль в личностной саморегуляции играет внешняя религиозная ориентация $\left(r_{s}=0,527, p \leq 0,01\right)$, которая может быть связана с предубежденностью к аутгруппам.

В группе молодежи с православными взглядами выявлена обратная корреляция этноаффилиативных тенденций с показателем антиконфессиональности $\left(r_{s}=-0.486\right.$ при $\left.p \leq 0,01\right)$. Так, чем выше стремление православных молодых людей быть принятыми в своей этнической группе, тем более выражена у них общность религиозных взглядов. Это выражается в соблюдении определенных правил, выработанных на основе схожих ценностей и идеалов.

Для православной молодежи с этнической индиф- ферентностью характерна наибольшая значимость религии, как независимой самоценности вне формальных требований и ритуалов $\left(r_{s}=0,515, p \leq 0,01\right)$.

Из полученных данных видно, что этническая принадлежность имеет большую значимость для молодежи с вероисповеданием ислама, чем для православных студентов.

Полученные результаты расширяют научные представления о связи межличностных отношений и религиозной идентичности с показателями этнического самосознания молодежи с разными религиозными взглядами, а также могут быть использованы в работе с молодежью по развитию этнической толерантности.

\section{ЛИТЕРАТУРА}

1. Андреева Г.М. Психология социального познания: учеб. пособие. - Аспект-Пресс, 2004. - 288 с.

2. Бузыкина Ю.С., Позднякова А.М. Теоретический анализ особенностей межэтнического взаимодействия в студенческой среде // Социальные практики в информационном обществе: сб. науч. ст. по материалам науч.-практ. конф. «ХІХ Социологические чтения» / под ред. Т.И. Лавреновой. - Пенза: Изд-во ПГУ, 2020. - С. 126-130.

3. Диагностика межличностных отношений: методика Т. Лири // Практическая психология в тестах, или Как научиться понимать себя и других / сост. Р. Римская, С. Римский. - М.: АСТ-ПРЕСС, 2001. - 393 с.

4. Лебедева Н.М. Этнопсихология: учебник и практикум для академического бакалавриата. - М.: Изд-во ЮРАЙТ, 2019. - 491 с.

5. Практикум по психодиагностике и исследованию толерантности личности / под ред. Г.У. Солдатовой, Л.А. Шайгеровой. - М.: МГУ им. М.В. Ломоносова, 2003. -112 c.

6. Семигодова Т.А., Бузыкина Ю.С. Показатели этнического самосознания у представителей разных этноконфессиональных групп // Актуализация персональных ресурсов личности: материалы Всерос. науч.-практ. конф. (очно-заочной) / под. ред. И.А. Медведевой. - Пенза: Изд-во ПГУ, 2020. - С. 122-127.

7. Соколовская И.Э. Религиозность и ее влияние на характер и личность современного человека. Конструктивные и деструктивные аспекты религиозности современной молодежи: научное пособие - М.: ВНИИгеосистем, 2013. - 170 с.

8. Стефаненко Т.Г. Этнопсихология: учебник для вузов. - М.: Аспект Пресс, 2009. - 368 с.

9. Толерантность и культурная традиция / под ред. М.Ю. Мартыновой. - М.: Изд-во РУДН, 2002. - 446 с.

10. Хертек С.С. Феномен религиозности в современном российском обществе // Вестник Бурятского государственного университета. - 2010. - №6. - С. 88-91.

11. Хухлаев Е.О., Шорохова В.А. Социально-психологическое исследование религиозной идентичности у православной молодежи // Социальная психология и общество. - 2016. - Т. 7. - № 2. - С. 35-50. 